\title{
Light Rail in Sydney: Some Privatisation Lessons
}

\author{
Gordon Mills
}

$\mathrm{T}$

THE new light-rail line in Sydney serves the inner suburbs of Ultimo and Pyrmont, and is expected to promote redevelopment as the old industries dition, the government of New South Wales may use the line as a base for extending light rail to other areas, including notably the central business district.

The line's new light-rail-vehicle technology meets engineering standards that far surpass those of Sydney's old tram network, which closed 36 years ago. But the commercial arrangements are, arguably, not so well conceived. So far, the government's infrastructure privatisation strategy has been based on so-called 'BOOT' contracts: in each, a private company builds, owns and operates the asset for a period during which it receives the asset's revenues; at the end of this franchise period, ownership of the asset is transferred to the government. It is argued below that it may be possible to alter and improve the contracting aims and procedures in order to secure the participation of private companies in a manner that better serves the public interest.

\section{The Genesis and Nature of the Pyrmont Light-rail Line}

The idea of re-establishing trams in Sydney's central business district (CBD) was taken up as early as 1974, when the Melbourne tram operator undertook a small feasibility study at the request of the NSW Minister for Transport. The CBD has an elongated shape, on a north-south axis. At the northern end is Circular Quay (still the site of the ferry terminal); at the southern end is Central Station, one of the six heavy-rail stations in the central area. The 1974 report considered two alternative routes running between Circular Quay and Central Station. As part of the proposed regime, most bus services reaching the CBD from the south and west were to terminate at Central Station, which was to become a modal interchange (Melbourne and Metropolitan Tramways Board, 1974:7, 21-2).

However, there was no realistic prospect of any re-introduction of trams in Sydney until September 1992, when the NSW government signed an agreement made under the Commonwealth government's Building Better Cities program. This agreement included 'a light rail project as a key element of strategies to revital-

Professor Gordon Mills is Director of the Centre for Microeconomic Policy Analysis at The University of Sydney. 
ise the Ultimo-Pyrmont area' (NSW Department of Transport, 1996a:2), an area that lies immediately to the west of the CBD. No doubt, the NSW government's appetite was whetted by the federal government's willingness to provide most of the $\$ 20 \mathrm{~m}$ or so envisaged as a capital subsidy. In 1992 , the total capital cost was thought to be about $\$ 40 \mathrm{~m}$.

The proposal was for a route of some 3.7 kilometres starting from Central Station, running west along city streets in Ultimo, and then turning north along an old (now disused) right of way for heavy rail, to serve the Pyrmont peninsula, which is separated from the CBD by Darling Harbour. Besides encouraging prospective developments, the eight intermediate stops were to serve recently established public buildings (such as the Powerhouse Museum and the Maritime Museum), and also the long-established Sydney Fish Markets.

Before inviting tenders from private companies for a BOOT contract, the NSW Department of Transport appointed a local consulting firm as its project manager for the process of preparing a light-rail scheme, and engaged a firm of US consultants to undertake design studies and to prepare 'a draft system specification for incorporation into the Expression of Interest documentation' (McLachlan Consultants, 1993b:1). In early 1993, it was intended to let the contract in February 1994, with operation planned to begin in early 1996 (McLachlan Consultants, 1993a:2). In the event, a project deed and a design-and-construct contract were signed on 2 December 1994, and came into effect on 29 November 1995 'when all the conditions precedent had been satisfied or waived' (NSW Department of Transport, 1996a:3).

According to NSW Department of Transport (1996a:1), the estimated total cost of the project (including capitalisation of interest) has risen to $\$ 87.5 \mathrm{~m}$. The governments are providing $\$ 21.5 \mathrm{~m}$ of this sum, and also paid a further $\$ 3.5 \mathrm{~m}$ for project management and feasibility studies. The seven vehicles are likely to cost a total of about $\$ 28 \mathrm{~m}$, leaving (say) $\$ 56 \mathrm{~m}$ for construction of the track and other installations; this amounts to roughly $\$ 15 \mathrm{~m}$ per route-kilometre. The vehicles, built in Australia by the ABB group, are a locally adapted version of the 100 per cent low-floor Variotram. The cost of the vehicles has no doubt been pushed up by government specification of a very low noise level, resulting in the need to adapt the standard design. Similarly, the choice of a 100 per cent low-floor vehicle reflects government insistence on very high standards of accessibility.

The total cost of track and other installations depends on what relocation of services is needed. With most of the Pyrmont line on the old railway reservation, however, this should not have been a major factor. The NSW Department of Transport (1992:13-15) cites Melbourne experience. After increasing the figures given there by 20 per cent to make rough allowance for inflation, the identified costs for double track amount to roughly $\$ 2 \mathrm{~m}$ - $\$ 3 \mathrm{~m}$ a kilometre. Even if this estimate is too low, it is difficult to see how the figure reaches $\$ 15 \mathrm{~m}$ a kilometre. A partial explanation may be found in suggestions by local observers that in some respects the specification is more appropriate for heavy rather than light rail, and that the 
construction method is more expensive than that used in Melbourne. Even if these remarks are sound, it is not clear how such a situation has arisen.

\section{Ownership, Construction and Operation of the Line}

The (very complex) assembly of contractual arrangements made between a host of parties has not been made public. But, in keeping with provisions established by the NSW government (see NSW Treasury, 1995), the NSW Department of Transport (1996a) has prepared a Summary of Contracts. (In the remainder of this section, all page references are to that Summary.)

The principal private party is Sydney Light Rail Company Limited (SLRC), which is owned by AIDC Investments, Utilities of Australia and Legal and General Life of Australia. Besides the equity capital subscribed by these three companies, debt funding has been provided by Dresdner Australia and by ABB.

SLRC has established a wholly-owned subsidiary, Pyrmont Light Rail Company Pty Limited (PLRC). The latter's roles are, first, to design and construct (the company has engaged $\mathrm{ABB}$ as sub-contractor to supply the vehicles and construct the fixed installations); and second, to operate, maintain and repair during the concession period of 30.5 years (the company has contracted with TNT for all this, while TNT has in turn appointed $\mathrm{ABB}$ as a sub-contractor for the maintenance and repair of vehicles) (p. 4). PLRC also leases from the State Rail Authority (SRA) the right of way (p. 7).

Throughout the concession period, PLRC determines the fare levels and receives the fare revenue. Evidently, the government of the day did not consider economic regulation of fares to be desirable in this instance. If the Department of Transport 'requires PLRC to carry passengers for free or at concessional fares, it must pay PLRC for any expenditure it incurs or revenue it forgoes as a result' ( $p$. 11). This raises the question of how to estimate the number of extra passengers who travel on concessionary fares but who would not pay the full fare.

It seems that PLRC does not pay any rent for the right of way. However, the company is to pay to the Department of 'Transport 'one-third of net passenger revenue (total passenger revenue less tax liability) from patronage in excess of 80 per cent of [prescribed] 1993 patronage estimates' (p. 20). Except to this extent, the risk that patronage fails to meet expectations is borne by PLRC (subject to an important qualification discussed in the next section). If PLRC fails to provide punctual service, it must pay certain damages to the Department (p. 11); but this obligation is severely limited by some provisions that are discussed below.

When the project deed was signed in December 1994, the date for completion was 30 June 1996. Because of delays in finalising the contract documents, PLRC successfully sought an extension (p. 10); when the deed became unconditionally binding in November 1995, the agreed date was 24. March 1997. If there is any delay in completion, PLRC is liable for liquidated damages of $\$ 10,000$ a day, up to a maximum of $\$ 3 \mathrm{~m}$ (p. 11). However, in September 1995 (because of delays then being experienced in satisfying all the conditions precedent to the Project Deed), the Department of Transport agreed to waive this right to liquidated damages, pro- 
vided the line was completed by 1 September 1997. It also agreed that, if completion occurred after 1 September 1997, liquidated damages would apply only for each day after that date. However, the deed 'specifies that [these] liquidated damages liabilities to the [Department] will arise only once PLRC has satisfied its liabilities to Dresdner and ABB Leasing under its project debt financing arrangements' (p. 11). In other words, payment of any liquidated damages would be postponed; the repayment of debt takes precedence. (A similar provision for postponement applies to the payment of any liquidated damages arising from lack of service punctuality.) In the outcome, the line started carrying passengers on 11 August 1997.

\section{Some Risk Provisions in the Privatisation Contract}

The company has managed to establish several provisions which limit its exposure to risk, including even some of the revenue risk. (In the following, unattributed page references are again to NSW Department of Transport, 1996a).

Risks arising from the company's own actions. Under the Project Deed, the obligation of PLRC to proceed with the project did not become effective until the company had managed to make 'financing arrangements sufficient to fund construction and operation' (p. 9). Of course, the company's position in seeking such funding was bolstered by its being the franchised company under the terms of the Project Deed.

PLRC was required to lodge a security of $\$ 2.5 \mathrm{~m}$ with the Department of Transport to back 'its obligations to finance, design, construct and commission the project ... [This] security had to be in the form of cash, an unconditional bank guarantee or another form approved (by the Dept. of Transport)' (p. 10). The Summary (p. 9) describes this condition as being 'for the parties' mutual benefit'. Relative to the monetary value of the public sector inputs that are put at risk, a security amount of only $\$ 2.5 \mathrm{~m}$ seems rather small.

Risks arising from the actions of third parties. The new Sydney Casino is expected to be a major traffic generator. Owned by a private company, it has a licence granted by the NSW government, and already operates in temporary premises. 'If the permanent Casino opens for trading more than twelve months after the light-rail system is completed, or after 31 March 1998 if this a later date, the IDepartment of Transportl will be liable to pay PLRC \$8,219 per day until the Casino opens' (p. 12). (It is now most unlikely that this provision will be invoked.)

Risks arising from the actions of government. The major protections obtained by PLRC relate to actions of governments. The Project Deed became effective only after the company had received from the (federal) Taxation Office a binding (private) tax ruling concerning the treatment of company revenues and costs, in a form that satisfied PLRC. The company carries the risk of any subsequent changes in general (federal) taxation law (pp. 9, 20). 
The other protections relate to actions of the NSW government. Besides a large number of matters directly related to the usual issues that arise in business contracts, the protections include these:

- 'If land tax is levied on PLRC, the Department of Transport will reimburse this amount' (p. 21).

- The Department of Transport expressly acknowledges 'that the light-rail system is intended to be the primary public transport link between the UltimoPyrmont area and Central Station'. The Department must consult with PLRC before permitting any new or extended regular passenger service in the area, and, in the event of such introduced services resulting in provable detrimental effect on PLRC's revenues, the Department will be liable to compensate PLRC for that company's losses (p. 12). (Incidentally, this conflicts with the spirit (at least) of the new national policy on infrastructure access.)

This last provision illustrates a common phenomenon in the privatisation of transport infrastructure (Mills, 1996): the private company seeks to prevent competition, and insists on the right to receive compensation should the government permit new entry. One effect of this practice is to place any monopoly rent in the hands of the private company. ${ }^{1}$ Another is to constrain the government in its future role as urban planner.

In summary, a company that is highly risk-averse has been able to secure some very significant protections, to such an extent that the usual efficiency claim for privatisation is called into question. The company has also secured an extra provision relating to the possible introduction of further light-rail routes; this matter is so important as to merit extended discussion in the following sections.

\section{Network Expansion: Opportunism or Long-Term Strategy?}

Among the extension possibilities, a north-south loop line running between Circular Quay and Central Station seems by far the most important. Such a route would reestablish a tram service first created in 1861 when the NSW government introduced horse-drawn cars - after contracting out construction and operation. The successor electric-tram services became very popular indeed. By 1925, the loop line alone carried about $30 \mathrm{~m}$ passengers annually, partly because the government tramways management encouraged tram travel even for relatively short intra-CBD journeys (Keenan, 1979, 1991; NSW Government Tramways, 1930). Of that loop-line traffic, approximately $20 \mathrm{~m}$ passenger-journeys both started and terminated within the

\footnotetext{
${ }^{1}$ Although historical precedent does not excuse this arrangement, it is worth noting that while 19thcentury British legislation commonly permitted construction of rival inter-urban railway lines, US practice often afforded a local monopoly. An early and influential example of the latter is to be found in the 1831 charter of the Boston and Worcester railroad: see Salsbury (1967:86).
} 
CBD (Neale, 1933). Intra-CBD journeys on all tram routes may have totalled $60 \mathrm{~m}$ annually.

Since that time, many changes may have affected the demand for intra-CBD service. Although heavy rail now runs through the CBD, all stations are inconvenient in access; headways are large; and punctuality is not part of the State Rail Authority culture. In consequence, these services offer little or no competition for such passengers. The present bus services are also unattractive: routes are complex and obscure, service is unreliable, and in some streets bus stops are poorly distributed. Although there appear to be no official data, informed commentators suggest that the buses presently carry at most $12 \mathrm{~m}$ intra-CBD passengers annually. This is probably only a fraction of the demand that would materialise if the CBD had highquality public transport. ${ }^{2}$

This background may help to explain the Department of Transport's interest in extending light-rail services to other areas, including the CBD. It is not the purpose of this article to consider whether it is in the public interest to introduce light rail rather than to seek, by some means or other, a major improvement in the quality of the bus services. But it is worth noting that, in the CBD much more than in other areas, light rail has two significant advantages. In a CBD that has narrow streets, it is relatively difficult to operate large-scale bus services, and there is an especial premium on the low-noise and other relatively benign environmental characteristics of light-rail technology. A light-rail franchise for the CBD may also be a very attractive financial proposition.

In the event, the Pyrmont contract has important extension provisions (NSW Department of Transport, 1996a:12-13): 'If the [Department] intends to extend the Ultimo-Pyrmont light-rail system (e.g. to the west or into the CBD) or have other light-rail routes join the system, it must ... negotiate with PLRC on terms and conditions' under which such services are to be provided. If the parties do not reach agreement within 90 days, the Department is allowed to call for tenders from other companies. If the Department accepts such a tender, then the successful tenderer must buy out the PLRC assets, on terms that depend on the timing:

- if the purchase occurs during the construction period of the Pyrmont line or within a year of the start of operations of that line, then the price to be paid 'is the agreed total cost of the project's works lafter allowing for the government fundingl, plus $20 \%$ interest';

- if the purchase occurs later, the price is ' 115 per cent of the fair market value of the system'.

The import of these provisions is to give the company first right of refusal on any other interconnecting light-rail projects that may be proposed.

$\overline{2}$ For more detail on this argument and on the historical precedents, see Mills (1997a). 
The economic and financial effects of this right depend on whether or not there are any significant economies of scope: that is, whether it will cost less to operate the Pyrmont and CBD services as an integrated whole. If there are no economies from joint operation, then the deal has distributive, financial consequences only: any other tenderer would have to bid high, to cover the extra cost (of 15 per cent of the fair market value of the Pyrmont line). In turn, this allows SLRC to bid high and still win, should the Department of Transport be so obstinate as to insist on going to tender. Thus, a bidding competition could never result in a contract that was expected to return only a competitive rate of profit on the new line (considered by itself).

On the other hand, there may be significant cost savings from joint operation: in particular, in respect of depot facilities (discussed below). If the capitalisation of such savings exceeds 15 per cent of the value of the Pyrmont line, the clause provides a way of promoting the emergence of an efficient, integrated operation. If the savings are less than that, effective bidding may be prevented.

Furthermore, by giving these extension rights to SLRC, the Department of Transport has entered into long-term commitments which may restrict its ability to shape public policy. If the arrangement deters pursuit of some preferred policy (perhaps one of later devising), there could be some adverse consequences for economic efficiency. Whatever the cost circumstances, the deal passes to SLRC a financial advantage, though conceivably this offer may have been needed to secure establishment of the Pyrmont line within the subsidy limit.

In contrast, the case of Manchester Metrolink shows how government can benefit by retaining control of extension possibilities: there, the public authority kept ownership of the assets, and the terms of the initial contract encouraged the authority to re-tender the operation of the entire system when the first light-rail extension was initiated. The new contract went to another consortium, which was willing to pay much more for the new concession (see Tyson, 1997).

In the Sydney case, there are also important questions concerning even-handed treatment of rival tenderers. In July 1993, the Department called for expressions of interest. In November 1993, after considering the responses, four groups were invited to tender. In May 1994, the four groups submitted a total of eleven proposals. On 30 June, the Department signed heads of agreement in favour of SLRC, 'setting out the broad parameters for the contracts to be negotiated' (NSW Dept. of Transport, 1996a:2). There followed five months of negotiation before the core agreements were signed.

Whenever significant private negotiation occurs, there is a risk that terms offered to the preferred tenderer would have produced better outcomes, in terms of the cost to the public purse and/or the users, and possibly even in terms of economic efficiency, if they had been offered to the other tenderers as well. A matter of special concern in the present case is the right of first refusal on extensions. The Summary of Contracts casts no light on whether all tenderers were informed that this was to be offered. In an interview in April 1997, officers of the Department stated that the invitation to tender did explain this, but did not spell out the 
(generous?) terms that were eventually offered to SLRC. The text of the invitation has not been made available, nor is it known whether the initial call for expressions of interest made it clear that what was at stake was the opportunity to develop light rail in Sydney as a whole rather than merely in the Pyrmont area. If there were no such intimation, some potential competitors may have decided not to express interest. More generally, the limited information that is available suggests that the competition for the Pyrmont contract may not have been very keen. In that case, it is not safe to conclude that the government secured a good deal on behalf of the users and taxpayers.

The public assurances do not address this issue. The Summary of Contracts was reviewed by the NSW Auditor-General who certified (on 16 April 1996), that 'nothing has come to my attention that causes me to believe that the [Summary] ... does not fairly evidence the contractual arrangements' (attachment to NSW Dept.of Transport 1996a). However, it appears that the Auditor-General was not asked to examine directly the process that led to the contracts being signed. On the other hand, the Minister for Transport did appoint a probity auditor to consider the tendering processes and the other steps. That auditor 'reported his satisfaction from a probity viewpoint' (p. 23). In the absence of a public statement describing the criteria applied by the probity auditor, it is not clear how much weight can be given to the assurance.

The remaining issue is why the Department would enter into such a long-term commitment. Was the decision taken because of myopic concerns for getting something done in the short term, and securing this at 'reasonable' (short-term) cost? Did the public servants (and the politicians) realise the significance of granting the company the first-refusal rights?

\section{Light Rail and the Sydney Transport Network}

The Pyrmont line is embedded in a transport network that is predominantly operated by public-sector agencies (many bus routes are served by private companies, but almost all of these are concentrated in the western suburbs, well removed from the central and inner-urban areas). Thus, in establishing through-ticketing, PLRC has to deal with City Rail and the State Transit Authority (which operates Sydney Buses and also Sydney Ferries).

In describing the light-rail project, the NSW Department of Transport (1996a:1) promises (rashly?) that 'Integrated, multi-modal ticketing will link the light-rail system with trains, buses, ferries and the monorail. Fares are anticipated to be broadly comparable with State Transit fares'. The monorail is presently a minor carrier, owned and operated by TNT and serving Darling Harbour. It seems that the monorail and the Pyrmont line will have through-ticketing. Passengers travelling between Pyrmont and the Town Hall area of the CBD could use both lines, with a reasonably convenient transfer.

Of greater importance to PLRC (and to the public interest) is facilitation of through travel between the Pyrmont line and the services of STA and SRA, many of whose passengers use weekly or other periodic travel passes. Cooperation may not 
be forthcoming from these public-sector organisations, especially in the case of the STA, for which extended light-rail services will present a competitive threat. Thus, PLRC may not gain access to travel pass revenues unless the Department of Transport so directs. At the time of writing, there are no signs that the Department is willing to take an active stance.

As and when light-rail services are extended to the CBD, the problems of network interdependence become even more important. On the demand side, separate ownership of light-rail routes would result in further contexts where revenue sharing would have to be negotiated if through-ticketing is to be established, and might also give perverse financial incentives to the individual light-rail operators. (The latter issue arises in the case of toll roads too: see Mills, 1995.) Thus, there are advantages in common ownership. (The concerns expressed earlier are about contractual terms rather than the practice itself.)

On the supply side, through running between the Pyrmont line and any CBD service will be a convenience, but may not be essential. Depot facilities for a CBD loop line could not be provided economically in the CBD itself, and would be better located on the Pyrmont line. If there were separate operators, this could be achieved by means of an appropriate financial arrangement.

A well-planned light-rail initiative should address all these issues at the outset. There are signs that the Department did consider many (if not all) of them. What may have been lacking is the political will needed for their resolution.

\section{Recent Developments}

In 1996, there were two important complementary developments, dealing with (respectively) extensions to the Pyrmont line and provision of a general legislative framework for light rail in New South Wales.

The latter is required because legislative repeal (undertaken after the abandonment of trams in ${ }_{3} 1961$ ) left some gaps, which hampered the development of the Pyrmont scheme. The Transport Administration Amendment (Light Rail) Act 1996 specifies procedures for dealing with planning, environmental and landownership issues in respect of light-rail lines. It also provides a legal framework for some aspects of operation, including fare-collection and third-party insurance: provisions that are needed for operation of the Pyrmont line.

Looking to the future, NSW Department of Transport (1996b) reported that the Department and SLRC had studied jointly the feasibility of extensions, including a SLRC proposal for a CBD service that would follow the route of the old tram loop-line, but with the vehicles travelling in the opposite direction on the loop; on balance, this may be a little less convenient for the passengers (Mills, 1997a). The government has now 'given in-principle approval to the concept of extensions and [has] approved the commencement of the necessary planning approval process' (circular issued by the Departmant of Transport, July 1997).

${ }^{3}$ Hansard, Legislative Assembly, 20 November 1996, p. 6347 and Legislative Council, 28 November 1996, p. 6771; see also Mills (1997a). 


\section{Policy Options}

The Pyrmont light-rail case shows how BOOT contracts can work in practice. The privatisation process attracts few private companies; there is extensive negotiation with a preferred tenderer; and the outcome gives to the private company terms that appear to be generous, at least in protecting the company from many of the risks. In short, the government does not secure widespread private-company interest, and seems not to be tough enough in its negotiating stance. As a result, service is provided at seemingly high cost to users and taxpayers.

In most respects, the Pyrmont case is like NSW government experience with BOOT contracts in respect of some toll roads and the new heavy-rail line which is to serve Sydney airport. But one exceptional feature of the Pyrmont case is the suspicion that construction costs may be higher than is appropriate, perhaps because of ambitious public-sector specification. Certainly, neither the public nor the private sector can rely on local skills in tramway design and operation, since these have largely disappeared after a gap of 36 years.

The challenge is to devise a superior approach to privatisation, one that may be pursued in the many infrastructure cases in which a government may wish to harness private-company skills to serve the public interest. The following discussion is intended to apply generally. In the application of the ideas to the construction of further light-rail lines in Sydney, allowance has to be made for the rights obtained already by SLRC. Since the contract details have not been made public - a disgraceful failure which is certainly not the tradition for disclosure of government business in the US - it is not possible to say with certainty whether that constraint is significant. If it is, then a government that shows determination, while respecting strict legal rights, may be able to resolve any difficulties.

One policy option is for the government to persevere with the use of BOOT contracts, but to seek better public-sector performance. Such improvement should focus on the following aspects:

- comprehensive analysis, in order to see far beyond the first contract (this is especially important in the context of transport and other networks);

- energetic dissemination of the analysis, to inform public scrutiny and to alert potential private-company tenderers and hence promote competitive interest;

- employment of tough, shrewd negotiators who care about their professional reputations even if they do not care about the public interest;

- careful specification of the contract for which bids are to be invited, helped perhaps by use of consultants to anticipate the features that might be sought by potential tenderers, thereby limiting if not eliminating the need for negotiation with a preferred tenderer; and 
- publication of the entire contract for which bids are to be invited, and subsequent publication of the signed contract, in order to provide an incentive for good public-sector performance and to inform public scrutiny.

Faced with this list, a public-sector official might argue that the aims are unrealistic: there simply are not very many interested companies, and any company that signs a contract inevitably wants commercial secrecy. On the latter point, once the contract has been signed, it is not clear that there is any commercial disadvantage arising from publication; on the other hand, the bureaucrats may well want to avoid scrutiny. On the former, lack of competition is a major issue; when this applies, government should adopt an alternative policy, as described below.

In the infrastructure context, the scope for, and benefit from, private-company participation is found principally (if not exclusively) in the construction and operation of the asset. On the other hand, private ownership brings few if any benefits (especially when the project is defined by the government), and often has disadvantages, especially in a network contract. In the alternative approach, then, the government invites private companies to bid for incentive contracts for operation and for construction (and perhaps design), while the government retains ownership of the asset. For some economic analysis of this, see Mills (1996b).

Also highly noteworthy is the proposal in Commonwealth Bank (1997), submitted to the Inquiry into Federal Road Funding, being undertaken by the House of Representatives Standing Committee on Communications, Transport and Microeconomic Reform. The Bank explicitly recognises a network difficulty, and proposes that government retain ownership in such circumstances. It suggests that construction of the asset be financed by means of fixed-interest non-recourse debt issued by the government: that is, bonds secured on the revenues of the asset rather than the government's general revenues. (For a brief economic consideration of the mechanism, see Mills, 1997b.) In broad terms, the financing procedure is like the practice used in a previous era of turnpike funding in the US. This approach could be employed for the Sydney light-rail CBD extension, which is likely to be financially self-supporting thanks to the anticipated high levels of patronage. At the least, the government could turn to this option if no private company is willing to offer a good price for the franchise.

The remaining question, of course, is how to make the public sector improve its performance, no matter what form of privatisation is to be used. Advocates of BOOT contracting argue that such privatisation is necessary because of publicsector shortcomings, but seem unwilling to recognise that the same poor performance can adversely affect the arrangement of privatisation contracts.

In the New South Wales context, the privatisation record as a whole leads to many concerns, so much so that recently the Auditor-General has publicly criticised the performance of successive governments (Sydney Morning Herald, 7 April 1997). There is no guarantee that this performance can be lifted. But public pressure may help. Indeed, it may be argued that, because concerns are so widespread, and the bureaucrats and the politicians so unwilling to allow public scrutiny of con- 
tractual and other details, there is a strong case for pressing the NSW government to establish an independent public inquiry into the privatisation record.

\section{References}

Commonwealth Bank of Australia (1997), Submission to the Inquiry into Federal Road Funding, House of Representatives Standing Committee on Communications, Transport and Microeconomic Reform, Canberra.

Keenan, D. (1979), Tramways of Sydney, Transit Press, Sydney.

- (1991), City Lines of the Sydney Tramway System, Transit Press, Sydney.

McLachlan Consultants (1993a), Ulimo Pyrmont LRT - Project Outline, Sydney. (1993b), Ulimo Pyrmont Light Rail Newsletter, Sydney.

Melbourne and Metropolitan Tramways Board (1974), Central Sydney Tramway: Feasibility Study, Mellourne (Report prepared for the NSW Minister for Transport).

Mills, G. (1995), 'Welfare and Profit Divergence for a Tolled Link in a Road Network', Journal of Transport Economics and Policy 29: 137-46.

- (1996), Public Infrastructure: Private Omership or Contracting Out?, Centre for Microeconomic Policy Analysis, University of Sydney, Sydney (Working Paper No. 18).

- (1997a), 'Back-Door Privatisation: Light Rail in Sydney', paper delivered at the Fifth International Conference on Competition and Ownership in Land Passenger Transport, Institute for Transport Studies, University of Leeds.

(1997b), Further Submission to the Inquiry into Federal Road Funding, House of Representatives Standing Committee on Communications, Transport and Microeconomic Reform, Canberra.

Neale, C. (1933), Effects of the Opening of the Sydney Harbour Bridge and Extension of Railways into the City on the Operation of Tramway Traftic, NSW Government Tramways, Sydney.

NSW Department of Transport (1992), Light Rail: Its Evolution and Potential for NSW, Sydney.

- (1996a), Ulimo-Pyrmont Light Rail Project: Summary of Contracts, Sydney.

(1996b), Light Rail Fact Sheets: Ultimo Pyrmont Light Rail Extensions, Sydney. (These six fact sheets are undated, but appear to have been issued in mid-1996.)

NSW Government Tramways (1930), Annual Report, Sydney.

NSW Treasury (1995) Guidelines and Principles for Private Sector Participation in the Provision of Public Infrastructure, Sydney.

Salsbury, S. (1967), The State, the Investor and the Railraad, Harvard University Press, Cambridge, Mass.

Tyson, W. (1997), 'Manchester Metrolink and the Private Initiative', paper delivered at the Fifth International Conference on Competition and Ownership in Land Passenger Transport, Institute for Transport Studies, University of Leeds.

The author undertook extensive revision of an earlier draft of this article during sabbatical leave spent at Laboratoire d'Economie des Transports in Lyon. 